\title{
THE INTERPLAY OF THE PRESENT AND FUTURE IN THE KINGDOM OF GOD (LUKE 19:11-44)
}

Laurie Guy

\begin{abstract}
Summary
The article argues that Luke has crafted Luke 19:11-44 to signal presentness as well as futurity in relation to the kingdom of God. The temporal reference of the parable in Luke 19:12-27 is not to be governed by verse 11 alone. Material in Luke 19:12-27 that is not in the equivalent Matthean parable has significant literary connection with subsequent material in verses 28-44. This subsequent material highlights the presentness of Jesus' kingship. What this shows is that Luke has subtly but carefully presented the kingdom of God as both present and future in the section under discussion.
\end{abstract}

\section{Introduction}

At first sight the function of 19:11 in Luke's narrative seems quite clear: 'As they were listening to this, he went on to tell a parable, because he was near Jerusalem, and because they supposed that the kingdom of God was to appear immediately.' The verse appears to provide the interpretative key to the immediately following parable, indicating that the kingdom is to be understood in terms of futurity and delay.

Closer analysis, however, reveals that this is only part of Luke's message. The parable and its introduction in v. 11 need to be read in the light of Jesus' subsequent entry into Jerusalem. This following material establishes a presentness to the kingdom to counter-balance the futurity of v. 11 and its parable. The literary connections between the parable and the description of Jesus' entry indicate that Luke's juxtaposition is 
deliberate. ${ }^{1}$ Through it he has created a richness of meaning which an exclusively futuristic understanding of the passage does not permit.

\section{Literary Interconnection in 19:11-44 as an Explanation of Difficulties in 19:12-27}

The parable that follows 19:11 is fraught with difficulty. Clearly there are awkward joins in the story, most obviously between vv. 26 and 27. Much, however, is resolved when one compares the parable with its parallel in Matthew 25:14-30. Luke's sub-plot, dealing with the venture to receive a kingdom, with the delegation to oppose that mission, and with the ultimate punishment of those in opposition, is lacking in Matthew. This raises the possibility that the subplot is a secondary addition to the parable. If the sub-plot material of $19: 12,14,15 a$ and 27 is deleted, a coherent parable remains. This suggests that either two separate parables have been spliced together or the main parable has been expanded. This article favours the second of these alternatives. The primary reason for this is that there are strong literary links between the additions and the two following pericopae (vv. 28-40 and 41-44), a point which will be developed shortly. In his Gospel as a whole Luke has displayed significant literary craftsmanship, and it is surprising if he joined together the two stories contained in 12-27 in apparently clumsy fashion, without obvious reason. On the other hand, if the additions are purposeful, not so much in relation to the pericope, but rather in linking the pericope with the succeeding material so that each is illuminated by the other, then there is reason for the discrete material in vv. 12-27 being united in one parable. ${ }^{2}$

\footnotetext{
${ }^{1}$ Other examples of juxtaposition of time frames in regard to the kingdom of God can be seen in the link between Lk. 17:20-21 and 17:2237, and the link of Lk. 9:27 with both 9:26 and 9:28-36.

${ }^{2}$ Most earlier discussions of this text have tended not to examine the wider literary links of this passage. Weinert, for example, draws from the earlier view of Jeremias that the story corresponds with earlier historical events in Judea. Weinert sees the sub-plot as a separate parable given as a warning to the audience not to rely on political
} 
Literary connection between vv. 12-27, 28-40 and 41-44 can clearly be substantiated. Linkage can firstly be noted in the way all three sections relate significantly to Jerusalem:
v. 11 He was near Jerusalem
v. 28 He went on ahead going up to Jerusalem
v. 41 He came near and saw the city

Further connection can be seen in the employment of $\beta \alpha \sigma i \lambda \varepsilon i \alpha /$ $\beta \alpha \sigma \imath \lambda \varepsilon v \omega^{\prime}$. The notion of receiving a kingdom and becoming king is quite central to the sub-plot in vv. 11-27 (see vv. 12, 14, $15,27)$. And in the following pericope Jesus is acclaimed as $\beta \alpha \sigma i \lambda \varepsilon v$ s, a significant Lukan departure from his Markan source. The subplot of receiving the kingdom in 19:11-27 is not a clumsy addition to a coherent parable, but is rather calculated craftsmanship by Luke, strongly signalling that vv. 11-27 are to be read in conjunction with vv. 28-38.

Another awkward aspect of Luke's parable is the words

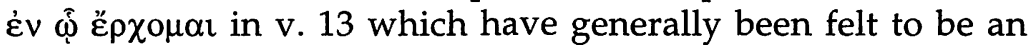
unusual form of expression. ${ }^{3}$ A literal translation is 'while I am coming' rather than 'until I come' (as RSV, NIV). Furthermore, the story at this point is discussing a 'going' rather than a 'coming'. If the literal rendering is followed, it implies that a coming is taking place now, whereas the story otherwise indicates that the coming is not yet-first the nobleman must

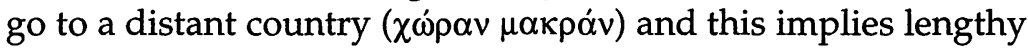
delay. The political intrigue surrounding the citizens' delegation also suggests delay. There is thus tension between the story and the final verb of $v$. 13. This article will suggest that this tension is deliberate. While the NRSV translation

strategies which worked in the past but will not work in the present eschatological situation. F.D. Weinert, 'The Parable of the Throne Claimant (Luke 19:12, 14-15a, 27) Reconsidered', CBQ 39 (1977) 505-14. See also P. Perkins, Hearing the Parables of Jesus (New York: Paulist, 1981) 146-47.

${ }^{3}$ Noted, for example, in J.A. Fitzmyer, The Gospel According to Luke (New York: Doubleday, 1979, 1985) II, 1235; J.A. Nolland, Luke (Dallas: Word Books, 1989, 1993) III, 914; M. Zerwick and M. Grosvenor, A Grammatical Analysis of the Greek New Testament (3rd ed.; Rome: Pontifical Biblical Institute, 1988) 258. 
'until I come back' provides smoothness to the story, a translation of this 'pregnant construction'4 which is faithful to the wording of the text and to the sense of the story, needs to embrace the dual concepts 'during the time I am away' and 'while I am coming (back)'.

Significance of 'coming' is highlighted in the following pericope which portrays Jesus as both 'the coming one' and 'the

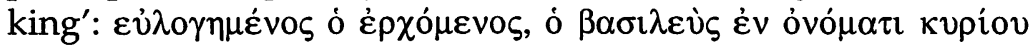
(v. 38). Here there are two descriptors of the one referent. "The coming one' seems in the first century to have been almost a technical term for Messiah. 5 Thus the two terms for Jesus under discussion here have marked messianic significance, and also have literary links with the nobleman/king of the parable who is coming.

Luke's significant literary skills displayed elsewhere in his Gospel suggest that the story-line awkwardness of the kingdom subplot in vv. 11-27 and the awkwardness of the reference to 'coming' in v. 13 are not the result of out-ofcharacter Lukan clumsiness. Luke has expressed himself awkwardly in the parable, not because this is the best way to narrate the parable, but because the awkwardness highlights that the parable must be read in conjunction with the material that follows, where 'coming' and 'king' have a great deal of significance.

This explanation answers Caird's assertion that the parable is not primarily about the kingdom, and therefore Luke's introductory comment that the purpose of the parable is to explain the delay of the kingdom, is rather off the point. 6 Caird's point is a fair one if the introduction is related to the parable alone and if the parable is an isolated unit unrelated to subsequent material. What literary connections have started to show, however, is that the parable is not an isolated unit but stands in close relationship with vv. 28-40. The two pericopae must be read together, each illumining the other.

Further literary connection between the two sections can be seen in the opposition to the nobleman's quest for

4Zerwick and Grosvenor, A Grammatical Analysis, 258.

5See, for example, Lk. 7:19; 13:35; Jn. 11:27; Heb. 10:37; Rev. 1:8.

6G.B. Caird, Saint Luke (Harmondsworth: Penguin, 1963) 210. 
kingship. If, as Caird observes, the primary focus of the parable is on the conduct of the servants, then the sending of the delegation to oppose the quest is irrelevant to the story. While the presence of the material has been partially explained as corresponding to the realities of Herod's accession, or of Archelaus' succession after the death of Herod, 7 nevertheless this does not clarify why the material is present in the Lukan parable in the first place. However, in the succeeding pericope we find material parallel to that presently under discussion. In v. 38 Jesus is acclaimed as king. The Pharisees oppose that kingship in v. 39: 'Teacher order your disciples to stop'. The opposition in v. 39 and the opposition of v. 14 are part of a textual web of interrelationship.

This web is shown too in the bloody end to the opponents. In the parable the order for the slaughter of the enemies of the king comes at a surprising time. The previous reference to opposition is back at v. 14. Thereafter there is a discussion of the king's dealings with his servants. The lack of further reference to the opponents leaves the reader to assume that the failure of their opposition has led to their fading out of the story. The parable appears to be wrapped up with a generalising moral in v. 26. Then comes the surprise of v. 27, with the order for the execution of the opponents, despite the earlier impression that they have by now dropped out of the story. One may argue that their fate has been introduced to provide completeness to the story. However, the loose ends are not in fact tied up. A despotic order is issued for the execution of the opponents in the presence of the king. But is it in fact carried out? And is it carried out in its entirety? Do any of the opponents escape? We do not know. The story ends, and we the readers are left wondering.

We have already noted, however, that unusual features of the parable seem to find explanation in their linkages with the two following pericopae. The literary enigma of $\mathrm{v} .27$ is to be explained in similar fashion. The slaughter of $\mathrm{v}$. 27 has literary connection with the slaughter of v. 44 .

7Josephus, War, 2.14-100; Ant. 17.224-300; Perkins, Hearing the Parables, 146-47. 
This article has already highlighted the opposition in $\mathrm{v}$. 39 to the proclamation of Jesus as king. There follows a general lament over the future fate of Jerusalem (vv. 41-44). While the opposition appears limited to some Pharisees, and the predicted destruction is to affect the whole populace, nevertheless the two sections are closely related. First the judgment is coming because the city has failed to recognise the things that make for peace (v. 41). 8 Yet peace is just what the disciples have proclaimed in connection with Jesus' triumphal procession (v. 38). Now while that proclaimed peace is peace in heaven, yet it is connected with the peace of v. 41, if only by repetition of a literary catchword-eipivi. And further literary association between the two sections is made through the echoing of the word $\lambda i \theta o s:$ 'The stones would shout out' (v. 40). 'They will not leave within you one stone upon another' (v. 44).

Another connection between vv. 41-44 and its preceding unit is the explanation that destruction will occur 'because you did not know the time of your visitation'

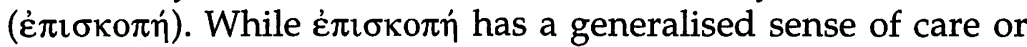
protection, here its mention as the basis of the horrific judgment suggests something of a more specific occurrence has taken place but not been recognised. In context, Jesus' approach to Jerusalem is that special occurrence.

In the previous unit the movement of Jesus to Jerusalem is by no means inconsequential. The deliberation with which animal transportation is arranged, the spreading of the cloaks on the road, and the exalted praise expressed by the disciples, all point to a moment of great significance. Though that significance is unrecognised, the procession to Jerusalem is an aspect of the visitation alluded to in v. $44 .{ }^{9}$

All of this shows close interconnection between vv. 2840 and vv. 41-44. With there also being significant links between vv. 11-27 and 28-40, this means that/all three pericopae have close interrelationship. This provides a likely

\footnotetext{
${ }^{8}$ In this regard note that Luke carefully limits the acclamation of Jesus to 'the whole multitude of disciples' (v. 37) in contrast to Mark and Matthew whose language suggests that the acclamation emanated from the people of Jerusalem.

${ }^{9}$ Fitzmyer, The Gospel, II, 1256.
} 
explanation of the riddle of v. 27. The mention of the slaughter is not included in that parable merely for the enhancement of that parable. Rather it is in that parable as a precursor of the terrible slaughter expressed in v. 44. There is literary connection between the two verses.

The foregoing investigation has established that there are strong links between the three units under discussion, and that such linking arises out of Luke's intentionality. The interconnections are a signal that each unit is to be read in the light of the others, and that no unit can properly be interpreted in isolation. This is a very important point, for Luke's intentionality in relation to the parable of vv. 12-27 has so often been assessed against v. 11 alone. ${ }^{10}$

While v. 11 is clearly important in interpreting the parable, it is not the sole governing factor. In particular, the foregoing discussion has highlighted that the parable must also be considered in the light of the material which is placed subsequent to it. Where v. 11 alone might seem to provide a clear-cut message about the timing of the kingdom's appearance, interrelationship between the parable and the subsequent material shows a far more nuanced understanding of the kingdom of God.

\section{19:11 as an Indicator of Delay in the Appearing of the Kingdom}

Turning to v. 11, we need to note that its vocabulary, style, the way in which it seems to produce a secondary application of

${ }^{10}$ Talbert is one who rightly recognises that 19:11ff. must be read in a wider context. His solution is to see the passage in the context of the Journey Narrative, starting at 9:51, and to view the parable as correcting an over-realised eschatology. In his understanding, Luke is showing that while the $\alpha v \alpha \lambda \eta \mu \psi \imath \varsigma$ was then impending, this is not to be confused with the coming of the kingdom which awaits the parousia. The weakness in Talbert's otherwise well-argued position is that he does not consider the subsequent narrative as part of Luke's context. Doing this produces a far more nuanced understanding of Luke's purposes here. C.H. Talbert, 'The Redaction Critical Quest for Luke the Theologian', in D.G. Buttrick (ed.), Jesus and Man's Hope (Pittsburgh: Pittsburgh Theological Seminary, 1970) 171-222. 
the parable, and other Lukan practice, all point to the verse being a Lukan introduction to the parable. ${ }^{11}$ As special Lukan material, it is very important data, reflecting Lukan theology in relation to the kingdom of God. Conzelmann, for example, relies heavily on this verse in arguing that Luke largely removed a sense of the imminence of the parousia from his Gospel, replacing it with a lengthy period of delay.12

Certainly a strong case can be mounted for this view. Jesus is now nearing Jerusalem. There is popular expectation that this signals the establishment of the kingdom of God. Later Jewish tradition indicated that 'the kingdom of Yahweh Sebaoth would be revealed over Jerusalem' (Tg. Isa 31:4-5). ${ }^{13}$ Such tradition may well be reflected in Acts 1:6: 'Lord, is this the time when you will restore the kingdom to Israel?' Thus 19:11 and its accompanying parable can be viewed as a corrective to popular eschatological expectations. The kingdom is not to appear immediately. A period of delay must first take place.

This viewpoint is strengthened by the linking of the pericope with the preceding story. Luke does this by the use of the connecting phrase 'as they were listening to this' ( $\dot{\alpha} \kappa o v o ́ v \tau \omega \nu \delta \dot{\varepsilon} \alpha \hat{v} \tau \hat{\omega} v \tau \alpha \hat{v} \tau \alpha$ ). Such a phrase causes the reader to refocus on the Zacchaeus story. After Zacchaeus' great display of repentance, restitution and generosity, Jesus pronounces, 'Today salvation has come to this house' (v. 9). The emphasis is on today ( $\sigma \dot{\eta} \mu \varepsilon \rho v)$, the word occupying an emphatic position in the sentence.

Salvation/deliverance was a popular Jewish hope. Now it has come today. For generations before and after the time of Jesus the Kaddish prayer had been uttered:

Magnified and sanctified be his great name in the world that he has created according to his will. May he establish his kingdom in your lifetime and in your days and in the

11Nolland, Luke, III, 912.

${ }^{12} \mathrm{H}$. Conzelmann, The Theology of Saint Luke (London: Faber and Faber, 1957, 1960) 113.

${ }^{13}$ See Fitzmyer, The Gospel, II, 1234. 
lifetime of all the house of Israel, even speedily and at a near time.

Salvation had now come, at least to one household. Did that mean that the hopes expressed in the Kaddish had also been fulfilled, that the kingdom had come? The declaration of salvation to Zacchaeus and the sweep of movement inexorably heading to Jerusalem (9:51), now only twenty-seven kilometres away, suggested an affirmative answer. With such a background of expectation, many scholars therefore argue that Luke deliberately inserts v. 11 to clarify that this is not the time of the appearing of the kingdom, that a period of major delay must first occur. ${ }^{14}$

Against this widespread view, there stands the divergent voice of L.T. Johnson. He turns the interpretation of delay on its head and argues that the parable of the ten pounds and its Lukan introduction indicates rather an immediate manifestation of God's kingdom. ${ }^{15}$

There has been little scholarly support and much challenge in regard to Johnson's arguments. ${ }^{16}$ In particular, Johnson's approach does not do justice to the parable. Lack of imminence, which is suggested by the editorial introduction, is further confirmed in the parable in the use of the term $\mu \alpha \kappa \rho \alpha$ v. This term indicates distance, and distance implies delay. This delay is further intimated by the sending of a delegation after the nobleman. Clearly the process would involve a lot of diplomacy, intrigue and argumentation. It would not take place $\pi \alpha \rho \alpha \chi \rho \eta \mu \alpha$. Accordingly, the parable implies delay rather than immediacy. Thus the broad consensus of interpretation of 19:11-27 is to be accepted and Johnson's views are to be laid aside. The parable is one of delay.

However, one of Johnson's arguments remains persuasive, namely that Luke's subsequent references are to an immediate kingdom. If Luke's subsequent references focus on an immediate kingdom, this does not necessarily negate the

\footnotetext{
${ }^{14}$ For example, Nolland, Luke, III, 913.

15L.T. Johnson, 'The Lukan Kingship Parable (Luke 19:11-27)', NT 24 (1982) $139-59$ at 152.

16See, for example, Nolland, Luke, III, 913.
} 
perspective that the parable of the pounds is a parable of delay. But it will give a much more nuanced understanding of it, a recognition that while it has a future orientation, there is present as well as future in the larger story of which the parable forms part.

\section{Subsequent Allusion in Luke 19 to an Immediate Kingdom}

We turn to Luke's story of Jesus' triumphal entry into Jerusalem (19:28-40). This very significant passage contains explicit declaration of Jesus' present kingship (v. 38). Does this declaration affect one's interpretation of the preceding parable which stands back-to-back with it?

Certainly there is connection in Luke's mind between the two passages. This has already been indicated in my earlier exploration of some of the difficulties of the Lukan parable. The subsequent story displays clear literary linkage with the preceding parable. In the first place the progression towards

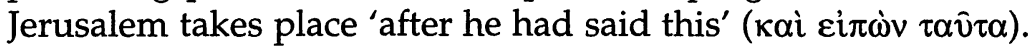
These words establish a link with the preceding pericope. That pericope has indicated that the kingdom will not appear immediately in Jerusalem. However, the subsequent story has an almost immediate declaration of Jesus' kingship in Jerusalem. So despite allusion to the non-appearance of the kingdom in v. 11, there is some sort of proclamation of the kingdom in the declaration of Jesus as king in v. 38. The apparent futurity of the kingdom in v. 11 must be read in the context of the presence of the kingdom in v. 38. The message of Luke is more complex and nuanced than first appears.

In the light of the apparent downplaying of any sense of imminent kingdom in v. 11, the subsequent declaration of Jesus' kingship at first seems rather surprising-but not to Luke. He has carefully crafted and shaped his story to prepare for this declaration. The procession itself has been a 
declaration of kingship. 17 The words of the crowd of disciples are simply a recognition of this.

Luke's stress on the royal implications of the final sector of the journey can be seen in the way Jesus procures an animal to ride on. The careful arrangements suggest that the riding itself is a statement, an act imbued with symbolic significance.

Jesus' pre-knowing the location and circumstances of the animal suggests the special nature of the occasion. One may speculate that Jesus has already made arrangements with the owner for the animal to be in that location. ${ }^{18}$ But this is to ignore the sense of mystery, the heightened sense of the numinous, that is starting to emerge as the story of Jesus is drawing to its climax. ${ }^{19}$ In this story Jesus is recognised as king; shortly Satan will enter into Judas (22:3); an angel will appear, to strengthen Jesus $(22: 43) ; 20$ eerie darkness will occur at noonday (23:44-45); and so on. This suggests that Jesus knows about the animal through God-given foreknowledge. Such foreknowledge alerts the reader to other aspects of the story which are also out of the ordinary. While Jesus' foreknowledge alone does not establish his unique kingship, it does prepare the climate for that idea.

Another feature of the organising of the animal which prepares the reader for the disclosure of Jesus' kingship is the fact that the animal is to be previously unridden. Derrett's argument, that the animal points to kingship, as no king would ride a previously ridden animal, is lacking in convincing

${ }^{17}$ Linkage between the triumphal entry and a kingship declaration is widely if not universally held. Thus J. Blenkinsopp ('The Oracle of Judah and the Messianic Entry', JBL 80 [1961] 55-64) commences his article with the words: 'We begin from the supposition that the entry into Jerusalem as recorded in all four gospels, is conceived both as messianic and royal proclamation.'

18So I.H. Marshall, The Gospel of Luke (Exeter: Paternoster, 1970) 710. ${ }^{19}$ Nolland, Luke, III, 922; Fitzmyer, The Gospel, II, 1249.

${ }^{20}$ This comment is made on the basis that these verses are integral to the Lukan text. See J. Neyrey, The Passion According to Luke: a Redaction Study of Luke's Soteriology (New York: Paulist, 1985) 55. 
supporting evidence.21 Better is Caird's noting that an unbroken donkey was 'pure' and so fit to be used for a sacred purpose (as in Nu. 19:2; Dt. 21:3; 1 Sa. 6:7).22 Again this intimates that this is no ordinary situation, and alerts us to the full significance of the imminent procession.

The taking of the animal in royal impressment also signals kingship dimensions of the entry story. In the ancient world, transport for state purposes operated in haphazard fashion, and was often requisitioned. ${ }^{23}$ This practice is highlighted in 1 Samuel 8:16, and possibly also in Numbers $16: 15$. A royal impressment would typically occur through the sending of messengers ahead to arrange for the next stage. The object to be impressed would be seized with explanation such as: 'I/the/army/the ruler requires this.' Commandeering for a secular ruler would be done in the name of ' $\mathrm{king} / \mathrm{lord}$ '.

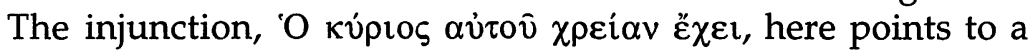
royal impressment.

Jesus' use of the term кúpros as a self-description heightens the sense of hierarchy and ascendancy in this passage. Elsewhere the Lukan Jesus commonly uses the ambiguous term 'Son of Man' to refer to himself. ${ }^{24}$ Certainly he frequently accepts others addressing him as kv́proৎ/'lord',25 although at times this may not carry much greater weighting than a respectful 'sir'. However, nowhere else in Luke's Gospel does Jesus refer to himself as kúpros.

The closest he comes to it is in 6:46 where he notes that others call him 'Lord, Lord', and in 6:5 where he asserts that he is lord of the Sabbath, though there his title for himself is 'Son of Man'. Thus Jesus' instruction to his disciples in verse 31 to justify their actions in terms of the requirements of o kúpios, Jesus himself, is most unusual. This is not just another incident

${ }^{21}$ J.D.M. Derrett, 'Law in the New Testament: the Palm Sunday Colt', NT 13 (1971) 241-58 at 248.

${ }^{22}$ Caird, Saint Luke, 218.

23Derrett, 'Law', 243.

$245: 24 ; 6: 5,22 ; 7: 34 ; 9: 22,26,44,58 ; 11: 30 ; 12: 8,10,40 ; 17: 22,24,26,30 ; 18: 8$, $31 ; 19: 10 ; 21: 27,36 ; 22: 22,48,69$.

$255: 8,12 ; 7: 6 ; 9: 54,59,61 ; 10: 17,40 ; 11: 1 ; 12: 41 ; 13: 23 ; 17: 37 ; 18: 41 ; 19: 8$; $22: 33,38,49$. 
in the life of Jesus. He seems to be acting out of character. As he described Gentile kings, so here is he behaving: lording it over others and exercising authority over them (22:25). On this one occasion Jesus is claiming royal authority and acting accordingly. He obtains the animal by royal impressment.

Though Mark's Gospel also has a sense of impressment, this is softened by the words 'and will send it back here immediately' (Mark 11:3b). Luke (also Matthew) significantly omits those words of softening. The sense of impressment is heightened.

The shout of acclaim in v. 38 provides further allusion to kingship. The Markan parallel (11:9) follows the LXX wording of Psalm 118:26. This psalm is one of the Hallel psalms used in conjunction with Judaism's great festivals. The cry of Psalm 118:26 is the customary cry of greeting for the festal

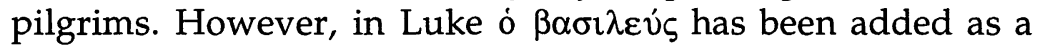
clarification of ó épxó $\mu \varepsilon v o \zeta$. Luke's description, now pertaining only to that one who is king, is a messianic acclamation. Moreover, the addition of $\beta \alpha \sigma \imath \lambda \varepsilon v$ s provides clear allusion to the LXX version of Zechariah 9:9: ó $\beta \alpha \sigma \imath \lambda \varepsilon v \dot{\zeta} \ldots . . . \dot{\varepsilon} \rho \chi \varepsilon \tau \alpha i$...


together the hosanna of Psalm 118:26 and the prophecy of Zechariah 9:9,26 again giving a sense of kingship.

The accession of Solomon in 1 Kings 1:28ff has helped shape the form of the Lukan story. 27 The Solomon narrative contains the following parallels to the Lukan story:

(1) there is emphasis on a band of people to accompany Solomon (1 Ki. 1:33, 38; cf. Lk. 19:37);

(2) there is stress on Solomon being placed on the royal mule (1 Ki. 1:33, 38);

(3) there is an acclamation of kingship (1 Ki. 1:39);

(4) there is an anointing of Solomon as king;

26E.E. Ellis, The Gospel of Luke (Grand Rapids: Eerdmans, 1966) 225.

27Tiede draws attention to this connection, and also relates the Lukan material to the enthronement of Jehu in $2 \mathrm{Ki}$. 9:13: D.L. Tiede, Luke (Minneapolis: Augsburg, 1988) 329. 
(5) this takes place at Gihon at the base of the Mount of Olives;28

(6) concern is expressed in relation to the acclamation by opponents (1 Ki. 1:41ff; cf. Lk. 19:39);

(7) the opponents are either killed or banished (1 Ki. 2; cf. Lk. 19:44).

Although some of the connections between the two stories are slight and uncertain, the parallels overall point to Luke (and probably his source/s) engaging in intentional intertextuality. While the Old Testament story focuses on the induction of Solomon into kingship, induction seems less explicit in Luke, although there is focus on the declaration of Jesus as king. Is this then an induction of Jesus into his kingship? One cannot give a clear answer to this question. It may well be that Luke had no clear answer to such a question either. His message here is subtle and suggestive, not spelt out in explicit language. However, all the overtones of the story point to Luke adorning the account with hints of Jesus' royal status.

Luke's omission of Mark's 11:10a $\varepsilon \dot{\lambda} \lambda \circ \gamma \eta \mu \varepsilon \dot{\varepsilon} v \dot{\eta}$

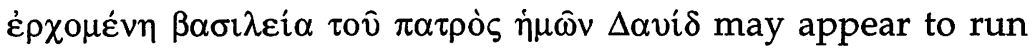
counter to my argument. However, a number of responses can be made which will satisfactorily deal with this objection. In the first place, Luke, who elsewhere in his writings seems to be at pains to stress the non-subversive nature of Christianity vis-àvis the Roman state, ${ }^{29}$ may well have dropped Mark's statement as being too much at risk of being misunderstood and viewed as subversive. Secondly, Mark's statement causes one to reflect on David, whereas Luke wants us to reflect on Solomon, on the Son of David. Finally, Luke may have omitted the Markan statement as redundant, having already

${ }^{28}$ We can note how Luke in 19:38 specifically locates the acclamation of Jesus as king 'at the descent of the Mount of Olives', though this geographical location is lacking in the other gospels. Observing that Jesus has come from Jericho via Bethany, and assuming that he crosses the saddle between Mount Scopus and the Mount of Olives, the end of his descent will be at Gihon.

${ }^{29}$ E.g., Lk. 23:4, 14-15, 47; Acts 16:35-39; 18:12-16; 26:30-32. 
recognised this aspect of the Markan account through the addition of the word $\beta \alpha \sigma \imath \lambda \varepsilon v$ s. Thus it appears that there is intertextual allusion to the acclamation of Solomon as king in the Old Testament, reinforcing Luke's message here that Jesus is now king.

Further intertextual allusion is contained in the spreading of the cloaks on the road (v. 36). The one similar incident in the Old Testament occurs at the acclamation of Jehu as king (2 Ki. 9:13). There the placing of the cloaks on the road is an act of homage paralleling the later response to the announcement of Jesus' kingship. Jesus' acceptance of this homage and affirmation of his kingship is shown in the way he refuses to silence the disciples as the Pharisees request. The disciples are right in what they are doing. Stones would have to take over the task if the disciples fell silent. There must be recognition at this time that Jesus is king.



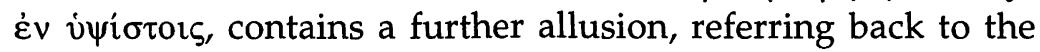
angelic praise in 2:14. That praise is the outcome of the birth of one 'in the city of David a Saviour who is the Messiah the

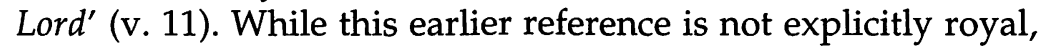
its marked messianic overtones make it implicitly so. Factors like this encourage the view that Luke's entry story significantly alludes to the kingship of Jesus. Intratextual connections strongly suggest that the interpretation of 19:11-27 must be assessed within the context of the material that has just been discussed. The kingdom will not appear immediately. And yet it will, for the king has come.

Against such an interpretation Fitzmyer argues that Luke intentionally altered Mark's reference to the Davidic kingdom to a reference to Jesus being king: Luke made the change from 'kingdom' to 'king' because declaration of a kingdom here would be incompatible with the postponement of the kingdom's appearance in 19:11. In Fitzmyer's words: 'It is not the kingdom of David that is coming, but Jerusalem's "king" himself'. 30

30Fitzmyer, The Gospel, II, 1251. A similar viewpoint is expressed in C.A. Evans, Luke (Peabody: Hendrickson, 1990) 289. 
Can the two be treated in such dichotomous fashion? Does not 'king' imply 'kingdom', and vice versa? In fact, an example of the equivalence of the $\beta \alpha \sigma \lambda \lambda$ - family of words can be seen in the preceding parable. When the nobleman seeks a kingdom ( $\beta \alpha \sigma i \lambda \varepsilon i \alpha v, v .12)$, the citizens send a delegation to assert that they do not want him to rule over them ( $\beta \alpha \sigma i \lambda \varepsilon v \overline{\sigma \alpha l}$, v. 14). Despite this, he receives the kingdom ( $\beta \alpha \sigma i \lambda \varepsilon i \alpha v, v .15)$ and subsequently asserts his right to rule ( $\beta \alpha \sigma i \lambda \varepsilon v \hat{\sigma \alpha \alpha}$, v. 27$)$. In such a context, where $\beta \alpha \sigma \nu \lambda$ - words are used virtually interchangeably, making a sharp distinction between $\beta \alpha \sigma i \lambda \varepsilon i \alpha$ and $\beta \alpha \sigma \nu \lambda \varepsilon v$ v seems unwise. Hence 19:38 is not a distancing by Luke from an imminent or present kingdom. Rather 19:38 is to be read in conjunction with 19:11. There is not yet a kingdom ( $\mathrm{v}$. $11)$, but there is a king, and so by implication there is a kingdom (v. 38).

Catchpole has helpfully drawn our attention to a family of stories extant in the first century detailing the celebratory entry to a city by a hero figure who has previously achieved a triumph. 31 An example of this is the journey of Alexander the Great from Gaza to Jerusalem. There his previously achieved authority is recognised without conflict. $\mathrm{He}$ is ceremonially met outside Jerusalem, greeted, and escorted into the city, and then to the temple where he is involved in cultic activity. 32

Drawing from twelve examples, Catchpole identifies a more or less fixed pattern of triumphal entry, exhibiting to a greater or lesser degree the following standard features:

(1) a victory already achieved and a status already recognised for the central person;

(2) a formal and ceremonial entry;

${ }^{31}$ D.R. Catchpole, 'The "Triumphal" Entry', in E. Bammel and C.F.D. Moule (eds.), Jesus and the Politics of his Day (Cambridge: Cambridge UP, 1984) 319-34. See also P.B. Duff, 'The March of the Divine Warrior and the Advent of the Greco-Roman King: Mark's Account of Jesus' Entry into Jerusalem', JBL 111 (1992) 55-71. Note too, Flender's earlier comment that 'the entry is like that of a general returning victorious from battle': H. Flender, Saint Luke: Theologian of Redemptive History (London: SPCK, 1967) 92.

32Josephus, Ant 11:325-29. 
(3) greetings and/or acclamations, together with invocations of God;

(4) entry to the city climaxed by entry to the temple (if there is one);

(5) cultic activity, either positive (e.g., offering of sacrifice) or negative (e.g., expulsion of objectionable persons and the cleansing away of uncleanness). 33

All of these aspects are present in Luke. The reference to 'deeds of power' (v. 37) and the recognition of the coming one as 'king' (v. 38) give a sense of victory and regal status. There are overtones of formal entry to the city with the careful arrangements made in relation to the $\pi \hat{\omega} \lambda \mathrm{o} \varsigma$ and the spreading of the cloaks on the road. Acclamation occurs and God is invoked with joyful praise (v. 37). The entrance into the city is followed by entry into the temple and its cleansing. No wonder Catchpole is able to say of the entry into Jerusalem: "There is an unmistakably kingly messianic colouring in the story.' 34 Luke portrays Jesus' entry into Jerusalem as a display of kingship.

While there has been a marked tendency to interpret and modify 19:28-40 in the light of 19:11, the entry into Jerusalem has been described with so much regal language and symbolism that it seems that Luke has intentionally made a statement here asserting the kingship of Jesus. Although Mark's version may be more future oriented, referring to 'the coming kingdom of our ancestor David', Luke's version in contrast is significantly past oriented. The acclamations of $\mathrm{v}$. $37 \mathrm{~b}$, followed by the declaration of Jesus' kingship in v. 38 joined by the word $\lambda \varepsilon$ ' demonstrated in 'all the deeds of power that they had seen'. Earlier in Luke those deeds of power were presented as a demonstration of the presence of the kingdom of God (11:20). Now such deeds are an exhibition of the fact that Jesus is king. This underscores the point that $\beta \alpha \sigma \imath \lambda \varepsilon i \alpha$ and $\beta \alpha \sigma \imath \lambda \varepsilon v$ s are not

${ }^{33}$ Catchpole, "The "Triumphal" Entry', 321. For a fuller discussion of triumphal entries in the context of the Lukan entry story see also B. Kinman, Jesus' Entry into Jerusalem in the Context of Lukan Theology and the Politics of His Day (Leiden: Brill, 1995).

${ }^{34}$ Catchpole, 'The "Triumphal" Entry', 323. 
to be seen in contrast. And the fact that the deeds are past indicates that Jesus' kingly rule also has a past and present dimension, and is not just something for the future.

This ties in with the entry stories discussed by Catchpole: all presuppose an already achieved victory, not a future one. ${ }^{35}$ Similarly, Luke focuses on past events (deeds of power have occurred). The king now enters his triumph on the basis of what has taken place in the past. Luke's emphasis in this pericope on the present dimension of Jesus' kingship makes it unwise to downplay the presence of the kingdom because of 19:11 and focus only on its futurity.

In his triumphal entry, Jesus' actions may have laid him open to misunderstanding, to popular, even misguided, messianic fervour. So be it. Now is the time to make a statement of his kingship to which the deeds of the past pointed.

It has been argued that 19:11 is clearly future, and that therefore all other apparently present-oriented statements about the kingdom must be understood in a futuristic sense. ${ }^{36}$ But that is to throw away ill-fitting pieces of the jig-saw puzzle or to distort their evident sense for the sake of establishing a uniform Lukan theology. ${ }^{37}$ That, however, may be to make an excessively large sacrifice at the sacred altar of consistency. Are we in danger of distorting the breadth, paradoxes and nuances of first century Lukan thought because of our twentieth century western understanding with its dichotomous

${ }^{35}$ Catchpole draws attention to this ('The "Triumphal" Entry', 322): 'They do not describe a first move or the opening of a campaign designed to achieve a future victory.'

${ }^{36}$ E.g., Conzelmann, The Theology, 122. Such a perspective seems to reflect Schweitzer's sharp dichotomy, that Jesus thought 'either eschatologically or uneschatologically': A. Schweitzer, The Mystery of the Kingdom of God: The Secret of Jesus' Messiahship and Passion (London: A. and C. Black, 1901, 1925) 86.

${ }^{37}$ Snodgrass makes a similar point in relation to Pauline thought: 'An important criterion by which any explanation of Paul's thought or of Romans can be judged is the question "What does the explanation do with the pieces that do not fit?" The pieces that do not appear to fit are telling criticisms of the inadequacy of our "systems".' See K.R. Snodgrass, 'Justification by Grace - To the Doers: An Analysis of the Place of Romans 2 in the Theology of Paul', NTS 32 (1986) 72-93. 
approach to logic and thought? Should we heed Ralph Waldo Emerson's warning: 'a foolish consistency is the hobgoblin of little minds adored by little statesmen and philosophers and divines'?38

We need to recognise the paradoxical nature of Luke's language about the kingdom of God. It is nuanced rather than straight-forward language. Earlier, in 9:27 and in 17:20-21, Luke has referred to a kingdom which, while future, also has present or near-present dimensions. Despite reference to futurity in 19:11, the subsequent material points in some sense to the presence or immediacy of the kingdom. Other allusions in the ensuing passion narrative display a similar pattern. ${ }^{39}$ What this means is that 19:11 and 19:28ff must be read together, neither subordinate to the other. There is not yet a kingdom, and yet there is a kingdom. Luke 19:11 points to a future kingdom, but this does not negate its present coming.

In summary, while 19:11 clearly indicates futurity, 19:28ff indicates a present coming of the king and kingdom (recognising, however, that this does not discount a later consummation). The key to integrating 19:11 and 19:28ff lies in a close study of the intervening parable. Although that parable affirms the futurity of the kingdom, its language foreshadows much of what follows in 19:28-44. There is tension within the parable, and within the larger Lukan passages under study, expressing tension within Lukan theology as a whole: the kingdom is future, but it is also present.

38R.W. Emerson in 'Self-Reliance' in Essays (Everyman's Library Series, London: Dent, 1906) 37. Note too Schechter's dictum to the effect that whatever faults the Rabbis may have had, consistency was not among them (quoted in N.T. Wright, The Climax of the Covenant [Minneapolis: Fortress, 1991] 4).

${ }^{39}$ Lk. 22: 16, 18, 29-30; 23:43. 